\title{
腸管出血性大腸菌 O157：H7をはじめとする食中毒菌に
}

\author{
対する食䣷の抗菌作用（その 2 ）殺菌作用に及ぼす \\ 塩化ナトリウムと温度の影響 \\ ${ }^{1)}\left(\right.$ 株) 中埜酢店中央研究所, ${ }^{2)}$ 名古屋大学医学部細菌学講座 \\ 円谷 悦造 ${ }^{1)}$ 浅井 美都 ${ }^{11}$ 辻畑 茂朝 ${ }^{1)}$ \\ 塚本 義則 ${ }^{1)}$ 太田美智男 ${ }^{2)}$
}

(平成 9 年 1 月 30 日受付)

(平成 9 年 2 月 26 日受理)

Key words: vinegar, Escherichia coli O157: H7, food-borne pathogenic bacteria, antibacterial activity, sodium chloride

\section{要旨}

腸管出血性大腸菌 O157：H7をはじめとする食中毒菌および一般細菌に対する種々の合せ酢の殺菌作 用を比較検討した。その結果，同一の酢酸濃度の合せ酢の殺菌力は，二杯酢>三杯䣷>甘酢の順で強い ことが判った。これは, 食酢の殺菌力が糖類により弱められ, 逆に塩化ナトリウムにより相乗的に強め られることによるものと思われた。塩化ナトリウムの代わりに㽜油を用いた合せ酢の殺菌力は極めて弱 かったが，この要因の一つとして $\mathrm{pH}$ の上昇が考えられた。

また, 食酢の酰酸酸度, 塩化ナトリウム濃度, 温度, 時間, 生菌数の 5 要素を多元的に解析し, 腸管 出血性大腸菌 O157：H7の殺菌条件を求めた. 更に, 食中毒対策としての, 食の場面での食酢の応用性に ついて検討した。その結果, 食酢に塩化ナトリウムを併用し, 温度の因子を加味することにより極めて 効果的な殺菌条件が得られることが判った。 その一つとして, 生菌数を 1,000 分の 1 に減少させる種々の 条件 (酶酸濃度, 塩化ナトリウム濃度, 温度, 時間の組み合わせ）を見出した。 また, これらの条件に おいて, 調理器具（まな板）抢よび生野菜（キャベッ, キュウリ）の殺菌試験を試みたところ, 食中毒 防止対策において実用性を示唆する結果が得られた。

\section{序文}

食酢は幅広い種類の微生物に対して抗菌作用を 有することが古くから知られているが1)，種々の 食中毒菌に対する抗菌作用を体系的に研究した例 は少な(2) 4). 特に, 平成 8 年に大きな問題となっ た腸管出血性大腸菌 Escherichia coli O157：H7 に対しては，䣷酸（食酢の主成分）溶液が食肉の 洗浄，殺菌に効果的であるとの報告が1990年代に 多くなされ, 総説5)としてもまとめられているが,

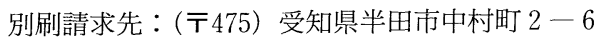

(株) 中埜酢店中埜中央研究所

円谷 悦造
食酢の抗菌性を検討した報告はなく，食酢が本菌 に抗菌性を示すか否かは明らかにされていなかっ た。この様な背景の中で，我々は食酢が腸管出血 性大腸菌 O157：H7に対して食酢が抗菌性を示す ことを明らかにし，前報6にてて報告した。

本報では，食中毒対策における食酢の実際的な 利用法を提示する目的で，腸管出血性大腸菌 O157：H7をはじめとする食中毒菌に対する合せ 酢の殺菌作用を検討し, さらに食酢（酶酸）の殺 菌作用に及ぼす塩化ナトリウムと温度の影響につ いて詳細に検討した。また，食の場面での応用性 についても検討した。 


\section{材料と方法}

1. 供試菌株

Escherichia coli serovar O157 : H7 NGY-10, E. coli serovar O26: H11 NGY-9688, E. coli serovar O111: K58: $\mathrm{H}^{-}$, E. coli serovar O55 IID 560, E. coli IFO 3208, Citrobacter freundii IID 976, Salmonella enteritidis IID 604, S. typhimurium NCI 17024, Morganella morganii IFO 3848, Vibrio parahaemolyticus RIMD 2210001, Aeromonas hydrophila IFO 3820, Pseudomonas aeruginosa IID 1031, P. fuorescens IFO 3081, Staphylococcus aureus IFO 3060, Enterococcus faecalis IID 682, Bacillus cereus IFO 13597, B. subtilis IFO 3007を供試した.

\section{2. 試薬}

食酢は，(株)中埜酢店製の酒精酢（酢酸濃度 10\%）を用い，これに次の試薬を添加した（注䣋 がないものは市販試薬使用，本報での濃度表示は 全て W/V\%)。塩化ナトリウム, ブドウ糖, 蔴糖, 酢酸ナトリウム，奨油（キッコーマン(株)製，濃 口酱油, 保存料無添加, 塩化ナトリウム含量 $18.2 \%)$. なお，酒精酢の酸成分は䣷酸が $100 \%$ で あり,酷酸以外の成分も $0.2 \%$ 程度と微量であるこ とから ${ }^{6)}$ ，本報では酒精酢（酶酸）と表現した。

3. 殺菌力の測定

1）殺菌試験溶液の調製

（1）合せ酢の殺菌効果

酢酸濃度 $2.5 \%$, 蔗糖濃度 $10 \%$ からなる合せ酢 (酒精酢と蔴糖), 酢酸濃度 $2.5 \%$, 塩化ナトリウム 濃度 $3.5 \%$ からなる合せ酢(酒精䣷と塩化ナトリウ ムまたは奨油), 酢酸濃度 $2.5 \%$, 蔴糖濃度 $10 \%$, 塩化ナトリウム濃度 $3.5 \%$ からなる合せ酢 (酒精酢 と蔗糖と塩化ナトリウムまたは酱油)を調製した。

(2) 試薬の添加効果

所定濃度のブドウ糖, 塩化ナトリウム, 䣷酸ナ トリウムを添加した酢酸濃度 $2.5 \%$ および $1.0 \%$ の酒精酰溶液を調製した。

（3）塩化ナトリウムの併用効果

$2 \%$ の酢酸濃度の酒精酢希釈液と $2 \%$ の塩化ナ トリウム溶液を調製し，両者を所定の割合で混合 した.
（4）塩化ナトリウムの併用効果に及ぼす温度の 影響

$0.5 \sim 2.5 \%$ の酒精酢由来の酢酸と $0 \sim 5 \%$ の塩 化ナトリウムを含む溶液を調製した。

2）供試菌体懸垂液の調製

$V$. parahaemolyticus RIMD 2210001, E. faecalis IID 682を除く細菌数はブイヨン寒天培地

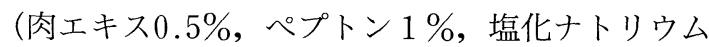
$0.5 \%$ ，寒天 $1.5 \% ， \mathrm{pH} 7.0)$ で $37^{\circ} \mathrm{C} ， 24$ 時間培養 後, 菌体を滅菌水に懸垂した。 V. parahaemolyticus RIMD 2210001は塩化ナトリウムを $3 \%$ 添 加したブイヨン寒天培地, E. faecalis IID 682 はト マトジュース寒天培地(トマトジュース濾液 $14 \%$, 肉エキス $0.5 \%$ ，ペプトン $1 \%$ ，ブドウ糖 $1 \%$ ，寒 天1.5\%，pH 6.5）を用いた。

3）殺菌試験

前報卓に準じた。

4. まな板の殺菌試験

使い古した傷のあるポリエチレン製まな板の表 面に, 腸管出血性大腸菌 O157：H7 NGY-10の菌 体懸垂液を塗布し15分間風乾した後，塩化ナトリ ウムを $3 \%$ 添加した酢酸濃度 $1 \%$ の酒精酢希釈液 を $9 \mathrm{~cm}^{2}$ 当り $2 \mathrm{ml}$ しみ込ませたふきんを載せ, $25^{\circ} \mathrm{C}$ にて放置した，所定時間放置後，供試菌体の塗布 部分を拭き取り，TC-SMAC 寒天培地（(株)ニプ 口製）にて腸管出血性大腸菌 O157：H7を選択的 に検出し, 検体 $6.25 \mathrm{~cm}^{2}$ 当りの生菌数を測定した.

5 . 生野菜の殺菌試験

千切りにしたキャベツを水洗後, 腸管出血性大 腸菌 O157：H7 NGY-10の菌体懸垂液に 5 秒間浸 漬した後引き上げ， 3 倍量の塩化ナトリウムを $3.5 \%$ 添加した酢酸濃度 $2 \%$ の酒精酢希釈液に, $50^{\circ} \mathrm{C} て ゙ 30$ 秒間浸漬した。浸漬後引き上げ, 滅菌生 理食塩水に入れストマッカーで粉砕した。粉砕液 の生菌数をまな板と同様の操作で測定し, 腸管出 血性大腸菌 $\mathrm{O} 157$ ：H7の検体1g 当りの生菌数を 算出した。また, 丸のままキュウリを用いて, 酢 酸濃度を $1 \%$, 処理温度を $40^{\circ} \mathrm{C}$, 処理時間を 35 分 とした以外は同上の方法で殺菌試験をした.更に， 菌を接種せずに同様の殺菌処理をした生野菜につ いて，食味の官能評価を行った。 


\section{成 績}

\section{1. 合せ酢の殺菌効果}

酒精酢を用いて酢酸濃度 $2.5 \%$ の杯酢 (塩化ナ トリウムまたは奨油添加), 甘酢 (蔗糖添加)およ び三杯酢（塩化ナトリウムまたは酱油および蔴糖 添加）を調製し，酢酸濃度 $2.5 \%$ の酒精酢希釈液と の殺菌力を比較した. Table 1 に腸管出血性大腸 菌 O157：H7を含む細菌14株での結果を示した が，塩化ナトリウムを加え二杯酢とすると殺菌力 は強くなり，逆に蔴糖を加え甘酢とすると弱く なった。塩化ナトリウムと蔗糖を使用した三杯酢 の場合は，二杯酢と同等ないしは二杯酢と甘酢の 間の殺菌力であった。また，奨油を用いた二杯酢， 三杯酢の殺菌力は塩化ナトリウムを使用したもの に比べ殺菌力は著しく低下した。これらの傾向は 供試菌株全般に認められたが，塩化ナトリウムの 添加効果は, 腸管出血性大腸菌 O157：H7, O26： $\mathrm{H} 11$ と腸管病原性大腸菌 $\mathrm{O} 111$ ：K58：H² 顕著 に発現し，殺菌に要する時間は各々 18 分の 1，60 分の 1 に短縮された。奨油を使用した合せ酢の

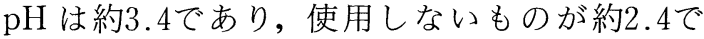
あったのに比べ高い值であった。

2. 塩化ナトリウムとブドウ糖の添加効果

酒精酢希釈液に塩化ナトリウムまたはブドウ糖 を添加し，酒精酢（酢酸）の殺菌力に及ぼす影響 を調べた。結果を Table 2 に示したが，供試菌株 全般において，酒精酢（酢酸）の殺菌力は塩化ナ トリウムの添加で強まり，ブドウ糖の添加で弱ま る傾向があり，腸管出血性大腸菌 $\mathrm{O} 157$ ：H7 NGY-10の場合は塩化ナトリウム $15 \%$ ，ブドウ糖 $45 \%$ の添加で殺菌力は各々 37.5 分の $1 ， 2$ 倍と なった。殺菌試験溶液の $\mathrm{pH}$ はほぼ同一であった。

3. 酢酸ナトリウムの添加効果

酒精酢希釈液に䣷酸ナトリウムを添加し，酒精 酢（酶酸）の殺菌力に及ぼす影響を調べた。結果 を Table 3 に示したが，供試菌株の全てに対する 酒精酢（酢酸）の殺菌力は酢酸ナトリウムの添加 により弱くなった。殺菌試験溶液の $\mathrm{pH}$ は酢酸ナ トリウムの添加量が多いほど上昇し, 酢酸濃度 2.5\%では，無添加，0.2\%添加，1\%添加， $2 \%$

Table 1 Bactericidal activity of AWASEZU (processed vinegar)

\begin{tabular}{|c|c|c|c|c|c|c|}
\hline \multirow{3}{*}{ Strains } & \multicolumn{6}{|c|}{ Time (min) necessary for sterilization at $30^{\circ} \mathrm{C}$} \\
\hline & \multirow{2}{*}{ Vinegar } & \multicolumn{5}{|c|}{ AWASEZU (processed vinegar) } \\
\hline & & AMAZU & NIHAIZU-I & SANBAIZU-I & NIHAIZU-II & SANBAIZU-II \\
\hline Escherichia coli O157 : H7 NGY-10 & 150 & 180 & 10 & 10 & 540 & 540 \\
\hline E. coli O26 : H11 NGY-9688 & 150 & 180 & 10 & 10 & 420 & 420 \\
\hline E. coli O111 : K58: $\mathrm{H}^{-}$ & 60 & 60 & 1 & 2 & 30 & 30 \\
\hline E. coli O55 IID 560 & 30 & 30 & 10 & 10 & 180 & 240 \\
\hline Citorobacter freundii IID 976 & 10 & 30 & 5 & 10 & 30 & 30 \\
\hline Salmonella enteritidis IID 604 & 10 & 10 & 5 & 10 & 30 & 30 \\
\hline S. typhimurium NCI 17024 & 10 & 60 & 2 & 2 & 60 & 60 \\
\hline Morganella morganii IFO 3848 & 10 & 30 & 5 & 10 & 30 & 30 \\
\hline Vibrio parahaemolyticus RIMD 2210001 & $<0.25$ & $<0.25$ & $<0.25$ & $<0.25$ & 0.5 & 0.5 \\
\hline Aeromonas hydrophila IFO 3820 & $<0.25$ & 0.75 & $<0.25$ & $<0.25$ & 0.5 & 0.75 \\
\hline Pseudomonas aeruginosa IID 1031 & 1 & 5 & $<0.25$ & $<0.25$ & 5 & 5 \\
\hline Staphylococcus aureus IFO 3060 & 10 & 30 & 10 & 10 & 120 & 150 \\
\hline Enterococcus faecalis IID 682 & 360 & 1,140 & 30 & 60 & 80 & 1,140 \\
\hline Bacillus cereus IFO 13597 & $>240$ & $>240$ & $>240$ & $>240$ & $>240$ & $>240$ \\
\hline
\end{tabular}

\footnotetext{
Vinegar $: 2.5 \%(\mathrm{w} / \mathrm{v})$ acidity vinegar

AMAZU $\quad: 2.5 \%(\mathrm{w} / \mathrm{v})$ acidity vinegar, $10.0 \%(\mathrm{w} / \mathrm{v})$ sucrose

NIHAIZU-I $: 2.5 \%(\mathrm{w} / \mathrm{v})$ acidity vinegar, $3.5 \%(\mathrm{w} / \mathrm{v}) \mathrm{NaCl}$

SANBAIZU-I $: 2.5 \%(\mathrm{w} / \mathrm{v})$ acidity vinegar, $10.0 \%(\mathrm{w} / \mathrm{v})$ sucrose, $3.5 \%(\mathrm{w} / \mathrm{v}) \mathrm{NaCl}$

NIHAIZU-II $: 2.5 \%(\mathrm{w} / \mathrm{v})$ acidity vinegar, $19.2 \%(\mathrm{v} / \mathrm{v})$ soy sause containing $18.2 \%(\mathrm{w} / \mathrm{v}) \mathrm{NaCl}$

SANBAIZU-II $: 2.5 \%(\mathrm{w} / \mathrm{v})$ acidity vinegar, $10.0 \%(\mathrm{w} / \mathrm{v})$ sucrose, $19.2 \%(\mathrm{v} / \mathrm{v})$ soy sause
} 
Table 2 Effect of $\mathrm{NaCl}$ and glucose on the bactericdal activity of spirit vinegar

\begin{tabular}{|c|c|c|c|c|c|c|c|c|}
\hline \multirow{4}{*}{ Strains } & \multirow{4}{*}{$\begin{array}{l}\text { Vinegar } \\
\text { acidity } \\
(\%, \text { w/v })\end{array}$} & \multicolumn{7}{|c|}{ Time (min) necessary for sterilization at $30^{\circ} \mathrm{C}$} \\
\hline & & \multirow{3}{*}{ none } & \multicolumn{6}{|c|}{ additives $(\%, w / v)$} \\
\hline & & & \multicolumn{3}{|c|}{$\mathrm{NaCl}$} & \multicolumn{3}{|c|}{ glucose } \\
\hline & & & 1 & 5 & 15 & 5 & 20 & 45 \\
\hline Escherichia coli $\mathrm{O} 157: \mathrm{H} 7 \mathrm{NGY}-10$ & 2.5 & 150 & 15 & 6 & 4 & 240 & 300 & 300 \\
\hline Escherichia coli IFO 3208 & 1.0 & 40 & $<10$ & $<10$ & $<10$ & 40 & 100 & 80 \\
\hline Pseudomonas fuorescens IFO 308 & 1.0 & 0.5 & $<0.25$ & $<0.25$ & $<0.25$ & 15 & 10 & 2 \\
\hline Staphylococcus aureus IFO 3060 & 1.0 & 90 & 60 & 30 & 30 & 210 & 210 & 210 \\
\hline Bacillus subtlis IFO 3007 & 1.0 & $>240$ & $>240$ & $>240$ & $>240$ & $>240$ & $>240$ & $>240$ \\
\hline
\end{tabular}

Table 3 Effect of $\mathrm{Na}$-acetate on the bactericidal activity of spirit vinegar

\begin{tabular}{|c|c|c|c|c|c|}
\hline \multirow{3}{*}{ Strains } & \multirow{3}{*}{$\begin{array}{c}\text { Vinegar } \\
\text { acidity } \\
(\%, \text { w/v) }\end{array}$} & \multicolumn{4}{|c|}{ Time (min) necessary for sterilization at $30^{\circ} \mathrm{C}$} \\
\hline & & \multicolumn{4}{|c|}{ Na-acetate concn $(\%, w / v)$} \\
\hline & & 0 & 0.2 & 1.0 & 2.0 \\
\hline Escherichia coli $\mathrm{O} 157: \mathrm{H} 7 \mathrm{NGY}-10$ & 2.5 & 150 & 240 & 420 & $>480$ \\
\hline Escherichia coli IFO 3208 & 1.0 & 40 & 80 & $>120$ & $>120$ \\
\hline Pseudomonas fluorescens IFO 3081 & 1.0 & 0.5 & 3 & $>10$ & $>20$ \\
\hline Staphylococcus aureus IFO 3060 & 1.0 & 90 & $>240$ & $>240$ & $>240$ \\
\hline
\end{tabular}

添加で，各々 $2.49 ， 3.35 ， 3.91 ， 4.19 て ゙ あ り ，$ 同 様に酢酸濃度 $1 \%$ では，各々 $2.80 ， 3.84 ， 4.53$, 4.56 であった。

4. 塩化ナトリウムの併用効果

同一濃度 $2 \%$ の酢酸（酒精酢）と塩化ナトリウ ムを所定の割合で混合した溶液に，腸管出血性大 腸菌 O157：H7 NGY-10の菌体懸垂液を接種し, 20分, 及び25分後の生菌数を Fig. 1 に示した。こ こで示されるように, 両者を混合した場合, 各々 の濃度は薄まるにもかかわらず, 殺菌力は顕著に 強くなった。最も殺菌力が強くなる酢酸濃度と塩 化ナトリウムの混合比は4：1であった。

5. 塩化ナトリウムの併用効果に及ぼす温度の 影響

$0.5 \sim 2.5 \%$ の酒精酢由来の酢酸と $0 \sim 5 \%$ 塩 化ナトリウムを含む, 種々の組み合せの殺菌試験

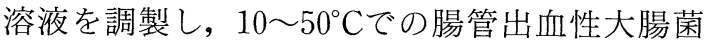
O157：H7 NGY-10に対する殺菌力 (死滅速度)を 測定した。それらから，食酢の酢酸濃度，塩化ナ トリウム濃度, 殺菌温度, 殺菌時間, 生菌数に扔 いて，任意に組み合わせた結果を引き出すことが できるが，その一例として，縦軸に生菌数を 1,000
Fig. 1 Synergism of vinegar and sodium chloride on bactericidal activity against Escherichia coli O157 : $\mathrm{H} 7 \mathrm{NGY}-10$ at $30^{\circ} \mathrm{C}$

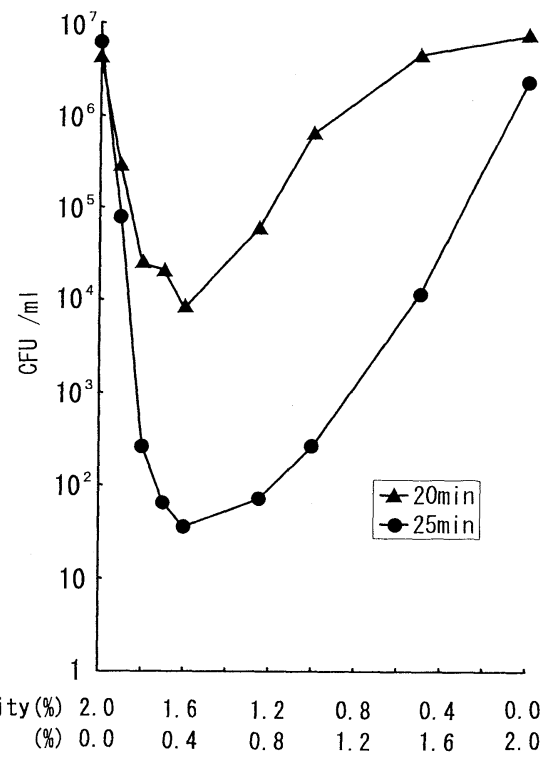

分の 1 に減少させ得る殺菌時間の対数, 横軸に塩 化ナトリウム濃度の対数を, 各酢酸濃度毎にとっ た結果を，Fig. 2 に示した。ここで示されるよう 
Fig. 2 Effect of sodium chloride and temperature on bactericidal activity against Escherichia coli O157 : H7 NGY-10 in spirit vinegar with 0.5, 1.0, 1.5, 2.0 , and $2.5 \%(\mathrm{w} / \mathrm{v})$ acidity
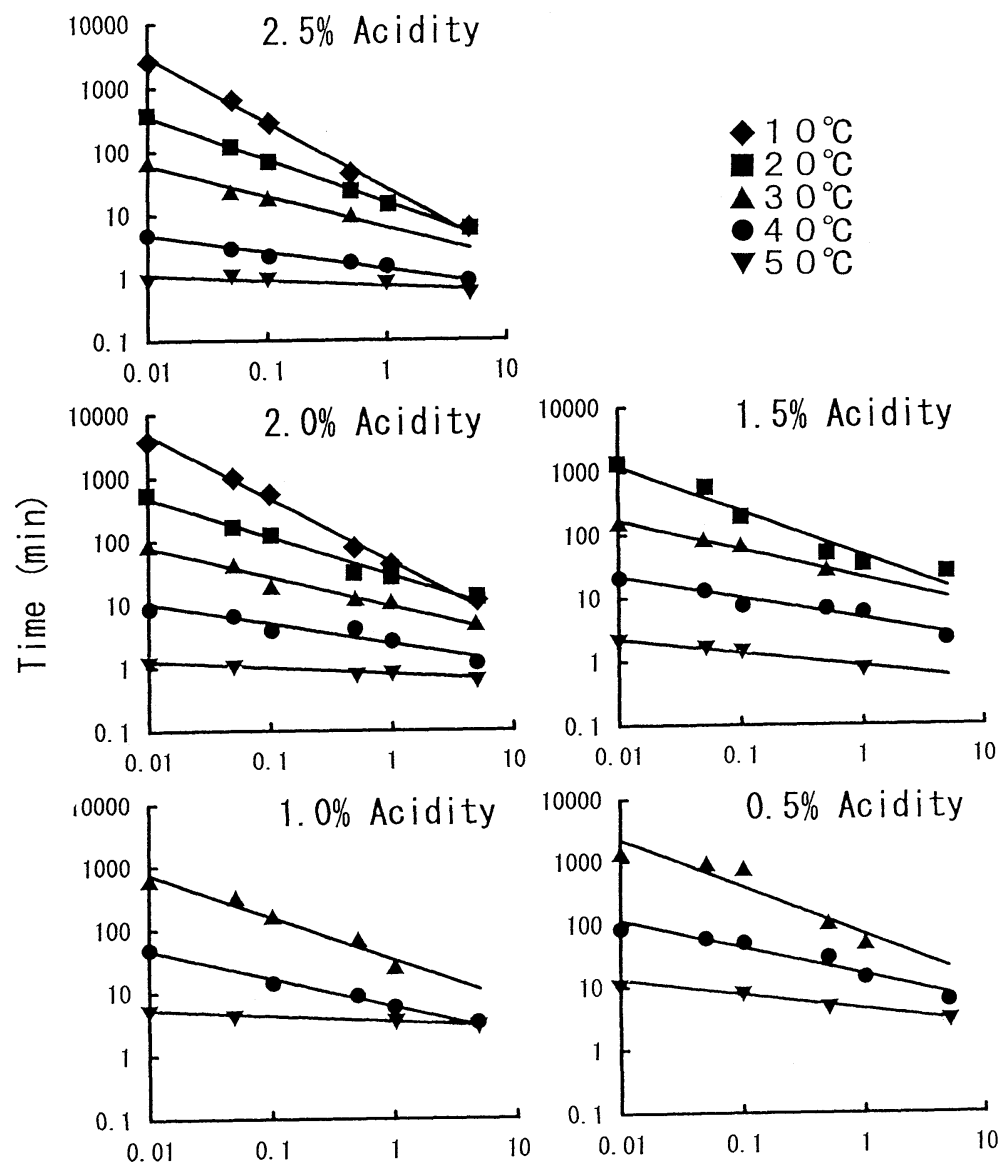

$\mathrm{NaCl}(\%)$

に，殺菌に要する時間の対数と塩化ナトリウムの 濃度の対数をプロットとすると直線が描けた。

また，解析例の一つとして，10分間で生菌数を 1,000分の 1 に減少させるのに必要な食酢の酢酸 濃度, 塩化ナトリウム濃度, 殺菌温度の関係を三 次元で図示した結果を Fig. 3 に示した。ここで得 られた局面の上部領域が, 10 分間で生菌数を 1,000 分の 1 以下に減少させることが可能な殺菌条件と して認識された。

6. まな板の殺菌

ポリエチレン製のまな板に腸管出血性大腸菌 O157：H7 NGY-10を接種して, 塩化ナトリウム を $3 \%$ 添加した酢酸濃度 $1 \%$ の酒精酢希釈液で殺 $-10^{\circ} \mathrm{C}$

$20^{\circ} \mathrm{C}$

- $30^{\circ} \mathrm{C}$

$40^{\circ} \mathrm{C}$

$\nabla 50^{\circ} \mathrm{C}$

1. $5 \%$ Acidity

$0.5 \%$ Acidity

\%)

菌処理をした。その結果, 初発生菌数 $4.5 \times 10^{7}$ $\mathrm{CFU} / 6.25 \mathrm{~cm}^{2}$ が，30分で $1.0 \times 10^{5} \mathrm{CFU} / 6.25 \mathrm{~cm}^{2}$ に，60分で検出限界の $10^{2} \mathrm{CFU} / 6.25 \mathrm{~cm}^{2}$ 以下にま で減少した。

\section{7. 生野菜の殺菌}

千切りキャベツに腸管出血性大腸菌 O157：H7 NGY-10を接種して, 塩化ナトリウムを $3.5 \%$ 添加 した酢酸濃度 $2 \%$ の酒精酢希釈液で殺菌処理をし た.また，キュウリを塩化ナトリウムを $3.5 \%$ 添加 した酢酸濃度 $1 \%$ の酒精酢希釈液で殺菌処理をし た。その結果，千切りキャベツを $50^{\circ} \mathrm{Cで} 30$ 秒間， また，キュウリを $40^{\circ} \mathrm{Cで} 35$ 分間殺菌処理すること により, 生菌数は 1,000 分の 1 以下, 即ち, 各々, 
Fig. 3 Relationship between acidity of vinegar, temperature, and sodium chloride to need three log decrease in bacterial number of cells of Escherichia coli O157: H7 NGY-10 in 10 minutes

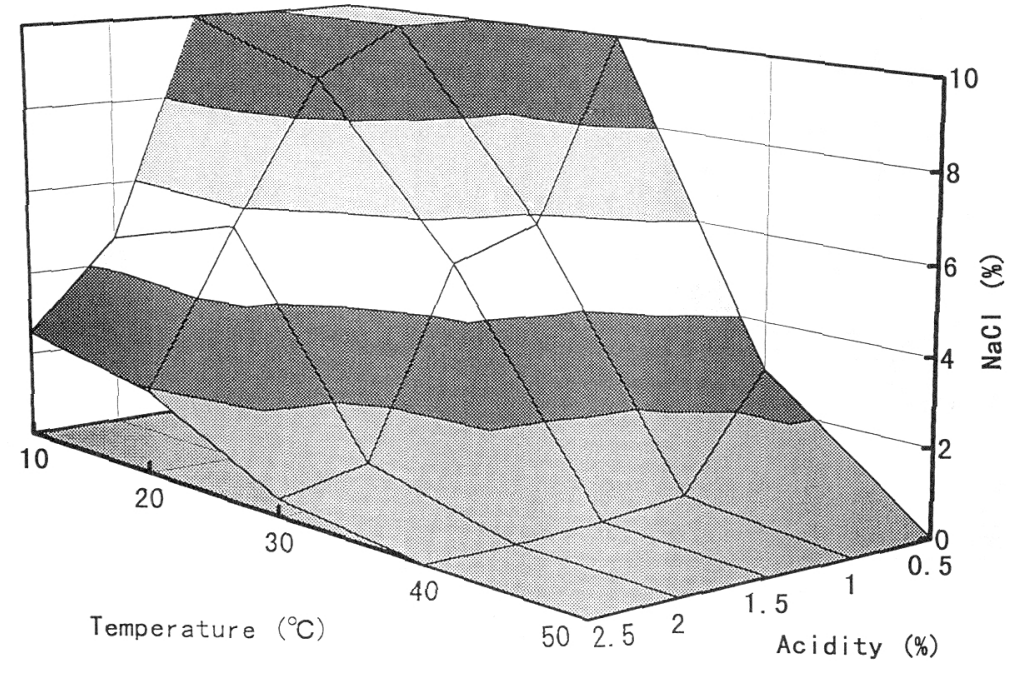

$1.5 \times 10^{5} \mathrm{CFU} / \mathrm{g}$ 加 $2.0 \times 10^{1} \mathrm{CFU} / \mathrm{g}, 6.1 \times 10^{5}$ $\mathrm{CFU} / \mathrm{g}$ から $1.2 \times 10^{2} \mathrm{CFU} / \mathrm{g}$ に減少した。菌を接 種せずに, 同様の殺菌処理をした生野菜の食味を 官能評価した。その結果, 味や物性の劣化は認め られなかった。

\section{考察}

食酢を調味料として用いる場合，砂糖，食塩， 蔣油等で調味を施し, 甘酢, 二杯酢, 三杯酢等の 合せ酢とすることが多い。そこで，合せ酢とした ときの腸管出血性大腸菌 O157：H7をはじめとす る食中毒菌および一般細菌の計14株に対する酒精 酢（酢酸）の殺菌力を調べた。その結果，供試菌 株全般に打いて, 合せ酢の殺菌力は二杯酷>三杯 酢>酒精酢>甘酢の順で強いことが分かった。ま た，醬油を用いた二杯酢および三杯䣷の殺菌力は 顕著に低いことが判明した。これらの現象の原因 を考察する目的で, 酒精酢の殺菌力に及ぼす塩化 ナトリウム, ブドウ糖および酢酸ナトリウムの添 加効果を調べた。その結果, $\mathrm{pH}$ は変わらないが塩 化ナトリウムの添加で酒精䣷の殺菌力は強まり, ブドウ糖の添加で弱まること, また, 酢酸ナトリ ウムを添加すると $\mathrm{pH}$ が上昇し, 殺菌力が顕著に 弱まることが判明した。このことから，合せ酢の 種類による殺菌力の差の要因として, 食塩, 蔗糖
の添加，醬油の使用による $\mathrm{pH}$ の上昇が考えられ た。

酒精酢の殺菌力は塩化ナトリウムの添加で強め られるが, 特にこの現象は腸管出血性大腸菌 O157：H7, O26：H11抒よび腸管病原性大腸菌 O111：K58：H-に対して強く発現した。そこで, 腸管出血性大腸菌 O157：H7 NGY-10を用いて酒 精酢と塩化ナトリウムの併用効果を検討した。そ の結果, 両者の間に極めて強い相垂的な殺菌効果 があることが分かった。

次に, より効果的な方法を考案する目的で前 報6に於いて報告した温度の因子を加味し，より 詳細な試験を実施した。そして, 得られた結果を もとに，任意な条件での殺菌効果を評価できるシ ステムを構築した。そのシステムより, 腸管出血 性大腸菌 O157：H7 NGY-100生菌数を1,000分 の 1 亿減少させ得る酒精酢の酢酸濃度, 塩化ナ卜 リウム濃度, 殺菌温度と殺菌時間の組み合わせを 見出した。例元ば，酢酸酸度 $2.5 \%, 20^{\circ} \mathrm{C}$ 条件下 で,生菌数を 1,000 分の 1 に減少させるのに要する 時間は, 塩化ナトリウムを $5 \%$ 添加すると 140 分の 1 に， $40^{\circ} \mathrm{C}$ にする51分の 1 に，両要素を併用す ると830分の100.89分に短縮できるという解析 結果が得られた。な拉, この試験の中で, 殺菌に 
要する時間と塩化ナトリウムの濃度を両対数でプ ロットすると直線性を示すことが判明した。この ことから, 外挿法により, 各酢酸濃度, 各殺菌温 度において，任意の食塩濃度での殺菌所要時間を 求めることができることが分かった。現在, 酢酸 濃度, 塩化ナトリウム濃度, 殺菌時間, 殺菌温度, 生菌数の 5 要素間での法則性を解析中であり, 追って報告の予定である。

更に，食の場面での利用の試みの一つとして， これらの試験で得られた殺菌条件の範囲内で, 生 野菜の殺菌試験を行った結果, 応用性があると思 われる結果を得た。ただし, 本試験では腸管出血 性大腸菌 O157：H7 NGY-10の生菌数を1,000分 の 1 に減少させ得る条件を見出したにすぎず，生 野菜などの食酢処理前の食材については, 少なく とも大腸菌群数が $10^{3} \mathrm{CFU} / \mathrm{g}$ 以下の清浄度が要求 されることに留意すべきである。また, 調理器具 についても検討したが, 金属性の器具の腐食を除 けば物性劣化を考慮しなくてよいことから，より 高濃度, 高温処理も可能と考えられ, 生野菜に比 べ応用性が高いと思われた。

本研究の結果から, 食酢と塩化ナトリウムを組 み合わせ，これに温度の因子を加味することによ
り，より効果的に食酢の殺菌作用を利用できるこ とが示唆された。しかし，ここでの結果は試験管 内ないしはモデル的なものであり，今後は実際の 場面での効果を数多く検証していく必要があると 考えられる。

本論文の要旨は1996年第33回日本細菌学会中部支部総会 に扔いて報告した。

\section{文献}

1）栗本末弘：天然物利用に上る食品の保存技術．食 酢(酶酸) の利用, 衛生技術会, 東京, $1981 ； 12-50$.

2）清水利貞, 鈴木一良, 出川 昭: 調味料中におけ る数種病原および食中毒菌の生存期間について。 日食工誌 $1962 ; 9: 198-200$.

3）円谷悦造, 柴田邦彦, 川村吉也, 正井博之 : 合せ 酢の殺菌作用について。 日食工誌 $1981 ; 28: 387$ -392 .

4）今井忠平,上杉郁子：マヨネーズの衛生管理(その 8 ) 追補と総括(下). 油脂 $1989 ; 42: 90-94$.

5) Corry JEL, James C, James SJ, Hinton M : Salmonella, Campylobacter and Escherichia coli O157: H7 Decontamination techniques for the future. Int J Food Microbiol 1995 ; 28 : 187-196.

6）円谷悦造，浅井美都，辻畑茂朝，塚本義則，太田 美智男：腸管出血性大腸菌 O157：H7をはじめ とする食中毒菌に対する食酢の抗菌作様（その 1 ) 静菌作用抢よび殺菌作用. 感染症誌 1997；71： 46-53. 
Antibacterial Action of Vinegar against Food-Borne Pathogenic Bacteria Including Escherichia coli O157:H7 (Part 2) Effect of Sodium

Chloride and Temperature on Bactericidal Activity

Etsuzo ENTANI ${ }^{1)}$, Mito ASAI ${ }^{1)}$, Shigetomo TSUJIHATA ${ }^{1)}$, Yoshinori TSUKAMOTO ${ }^{1)} \&$ Michio OHTA ${ }^{2)}$

${ }^{1)}$ Nakano Central Research Institute of Nakano Vinegar Co. Ltd.

${ }^{2)}$ Department of Bacteriology Nagoya University School of Medicine

Bactericidal effects of various kinds of AWASEZU (processed vinegar, 2.5\% acidity) on food-borne pathogenic bacteria including Escherichia coli O157:H7 and other bacteria were examined. The order of bactericidal activities was NIHAIZU (3.5\% NaCl was added) $>$ SANBAIZU $(3.5 \% \mathrm{NaCl}$ and $10 \%$ sucrose were added) $>$ plain vinegar (spirit vinegar) $>$ AMAZU $(10 \%$ sucrose was added). This indicates that their activities were enhanced by the addition of sodium chloride and suppressed by the addition of sugar. On the other hand, when soy sauce was used instead of sodium chloride, the order of bactericidal activities was plain vinegar $>$ AMAZU $>$ NIHAIZU $>$ SANBAIZU. This is mainly because their activities were suppressed by the increase in the $\mathrm{pH}$ value.

The effect of sodium chloride $(0.01-15 \%)$ and temperature $\left(10-50^{\circ} \mathrm{C}\right)$ on bactericidal activities against $E$. coli $\mathrm{O} 157: \mathrm{H} 7$ in spirit vinegar (0.5-2.5\% acidity) was further examined. When vinegar was used in combination with sodium chloride, predominant synergism on the bactericidal activity was observed. Their activities were markedly enhanced by the addition of sodium chloride in proportion to the concentration. In addition to this, at higher temperatures spirit vinegar killed bacteria much more rapidly. It should be noted that the bactericidal activity of spirit vinegar was extremely enhanced by the combined use of the addition of sodium chloride and the rise of temperature. For example, in $2.5 \%$ acidity vinegar, the time required for $3 \log$ decrease in viable cell numbers at $20^{\circ} \mathrm{C}$ was shortened to $1 / 140$-fold by the addition of $5 \%$ sodium chloride, shortened to $1 / 51$-fold by the rise of the reaction temperature at $40^{\circ} \mathrm{C}$, and shortened to $1 / 830$-fold; 0.89 minutes by both the addition of $5 \%$ sodium chloride and the rise of temperature at $40^{\circ} \mathrm{C}$.

In order to propose the methods to prevent food poisoning by bacterial infection, bactericidal activities of vinegar solution containing sodium chloride on cooking tools and raw vegatables were examined. Vinegar solution (1-2\% acidity, 3-7\% $\mathrm{NaCl}$ ) produced more than 3 log decrease in viable cell numbers of $E$. coli $\mathrm{O} 157: \mathrm{H} 7$ on the surface of cutting board, and cabbage and cucumber at $20-50^{\circ} \mathrm{C}$. These results suggested that the treatment with vinergar solution containing sodium chloride may be one of the useful methods to prevent food poisoning. 